\title{
A new dragonfly family from the Upper Cretaceous of France
}

Andre Nel, Didier Neraudeau, Vincent Perrichot, Vincent Girard, and Bernard Gomez

Acta Palaeontologica Polonica 53 (1), 2008: 165-168 doi:http://dx.doi.org/10.4202/app.2008.0113

This is an open-access article distributed under the terms of the Creative Commons Attribution License (for details please see creativecommons.org), which permits unrestricted use, distribution, and reproduction in any medium, provided the original author and source are credited.

Fof 